\title{
Etiek en Ou Testament. 'n Kritiese bespreking van Bybelse grondslae vir moderne etiese vraagstukke
}

\author{
H.F. van Rooy \\ Departement Ou en Nuwe Testament \\ Potchefstroomse Universiteit vir $\mathrm{CHO}$ \\ POTCHEFSTROOM
}

\begin{abstract}
Ethics and Old Testament. Biblical foundations for modern ethical problems

This article deals with the use of the Old Testamem in seeking answers to modern ethical issues. A distinction must be made between the ethics of the Old Testament - a field for Old Testament scholars and the use of the Old Testament by modern Christians in answering their ethical problems. The article focuses on the hermeneutical problem and the use of the Old Testament in three publications is discussed to illustrate this problem. This is followed by a discussion of the hermeneutical problem as it relates to the use of the Old Testament in addressing ethical problems. The article stresses the need for sound hermeneutics and exegesis when using the Old Testament in ethical discussions.
\end{abstract}

\section{Inleiding}

In die bespreking van die belang van die Ou Testament vir etiese vraagstukke moet twee sake goed van mekaar onderskei word. Ter wille van duidelikheid kan die twee sake onderskeidelik die etiek van die Ou Testament en die belang en die gebruik van die Ou Testament vir etiese vraagstukke genoem word. Die eerste saak is ' $n$ omvangryke veld op sy eie en is veral vir Ou-Testamentici van belang. Die tweede is ' $n$ baie breer saak met 'n wyer trefwydte en hou verband met die vraag na die gebruik van die Bybel (die sogenaamde Skrifberoep) om antwoorde op etiese probleme te kry. In hierdie verband het die gebruik van die $\mathrm{Ou}$ Testament besondere probleme, juis omdat dit die $O u$ Testament is. Dit hang saam met die hele vraag na die gesag van die Ou Testament en in die besonder met die plek van die Ou Testament in die kerk. Oor albei hierdie sake bestaan daar uiteenlopende menings en benaderings, wat nie in hierdie artikel aandag gaan ontvang nie. Eerstens gaan die vraag na die etiek van die Ou Testament bespreek word, met besondere aandag aan 'n raamwerk waarbinne die etiek van die Ou Testament benader kan word. So 'n raamwerk is belangrik omdat dit kan verhoed dat individuele gedeeltes wat met die etiek verband hou, op hulle eie, los van die groter verband van die Ou Testament, gebruik word in debatte oor etiese 
vraagstukke. Tweedens gaan die hermeneutiese probleem van die Ou Testament bespreek word met besondere aandag aan die gebruik van die Ou Testament vir die soek na antwoorde op etiese vraagstukke. Derdens sal enkele verteenwoordigende voorbeelde bespreek word in die lig van die voorafgaande bespreking.

\section{Die etiek van die Ou Testament}

Walter Kaiser het in 1983 daarop gewys dat die terrein van die etiek van die Ou Testament relatief min aandag gekry het (vgl. ook Bosman, 1983:97). In die eeu tot 1983 het net ses persone boeke oor diè onderwerp geskryf. Net twee van hierdie boeke verteenwoordig pogings om die hele veld van die etiek van die $\mathrm{Ou}$ Testament te beskryf en albei het reeds in die vorige eeu verskyn (Kaiser, 1983:1). Alhoewel enkele nuwe werke intussen verskyn het (vgl. Kaiser, 1983 en Wright, 1983a en b), is die prentjie tot 'n groot mate nog dieselfde. Dit is natuurlik onmoontlik om hier 'n volledige oorsig te gee oor die stand van navorsing ten opsigte van die etiek van die Ou Testament; daarom word op twee sake gekonsentreer, naamlik verskillende benaderings tot die etiek van die $\mathrm{Ou}$ Testament en 'n moontlike raamwerk vir die bestudering van die onderwerp.

\subsection{Verskillende benaderings}

In sy omvattende werk van 1983 onderskei Kaiser (1983:14-22) ses verskillende benaderings tot die etiek van die Ou Testament:

\section{- 'n Sosiologiese benadering}

Kaiser beskou Hempel en Barton as voorbeelde van hierdie benadering. Hempel was van mening dat daar drie groepe mense in die Ou Testament onderskei kan word, wat elk 'n eie benadering gehad het tot hulle lewenswyse en die samelewing waarin hulle hulle bevind het. Die drie groepe is die semi-nomadiese beesboere, die landelike bevolking en die stedelinge. Die beesboere het klem gelê op broederskap en die belange van hulle eie groep, die landelike bevolking was sterk gebonde aan die land en aan die voorvaderlike oorlewerings en die stedelinge was 'n samesmelting van Kanaäniete en Israeliete wie se finansiële en tegniese vermoëns hulle welvaart verseker het. Daar was dus nie sprake van 'n gemeenskaplike Israelities-etiese tradisie nie.

\section{- 'n Morele teologiese benadering}

Kaiser bespreek Hodgson as 'n voorbeeld van hierdie benadering. Hy onderskei vier aspekte ten opsigte van 'n morele benadering in die voor-Christelike Jodendom, naamlik die wil van God as die bron van verpligtinge, die gebruik van die mens se morele insigte om tussen reg en verkeerd te onderskei, die wet as die 
H.F. van Rooy

inhoud van God se wil en die sondige aard van verkeerde optrede verbind aan die mens se onvermoë om homself te genees.

\section{- 'n Sinkroniese benadering}

Vriezen is vir Kaiser die beste voorbeeld van hierdie benadering, waarin verskillende onderwerpe in die etiek van die Ou Testament bespreek word. God gee vir hom die eenheid in die Ou-Testamentiese etiek. Die sentrale motief vir die morele lewe is te vinde in die sense of community wat verbind word aan die gedagte van persoonlike verantwoordelikheid. Die wins van hierdie benadering is 'n soeke na eenheid in die etiek van die Ou Testament. Dié eenheid hou verband met die besondere klem wat die gemeenskap met God in Vriezen se benadering tot die Ou Testament speel.

\section{- 'n Diakroniese benadering}

Mitchell en Eichrodt het die etiek van die Ou Testament in sy kronologiese ontwikkeling bestudeer. Mitchell se ordening sluit aan by die kritiese siening van die bronne van die Ou Testament. Eichrodt onderskei drie dimensies wat hy aan drie sinkroniese temas verbind, naamlik die norme, materiaal en motiewe van morele optrede.

\section{- 'n Benadering uitgaande van 'n sentrale tema in die Ou Testament}

In hierdie benadering word 'n sentrale tema gekies as 'n sleutel vir die verstaan van die Ou-Testamentiese etiek. Muilenburg kies gehoorsaamheid, Flesseman die heiligheid van God, Kornfeld die wil van God en Kinlaw die skepping.

\section{- 'n Omvattende benadering}

Kaiser self wil 'n meer omvattende benadering volg, in aansluiting by die benadering van W.S. Bruce, waarin hy aandag wil gee aan definisie en metodologie, die Dekaloog en ander kerngedeeltes, die inhoud (sinkronies) van die Ou-Testamentiese etiek, morele probleme en die verbinding met die Nuwe Testament. Wat hierin nie apart genoem word nie, en wat waarskynlik ook belangrik is, is die diakroniese ontwikkeling van die Ou-Testamentiese etiek. Kaiser se eie benadering is baie sterk sinkronies. Hierin moet natuurlik onthou word dat die Ou Testament deel is van die kerk se kanon en dat die $\mathrm{Ou}$ Testament ook relevant is vir die bestudering van moderne etiese vraagstukke (vgl. Barton, 1985:114-115). Hierdie beklemtoning speel 'n belangrike rol in Wright (1983b:10) se benadering, soos ook blyk uit die subtitel van die boek in die vorm waarin dit in Engeland gepubliseer is: Living as the people of God. The relevance of Old Testament ethics. Dieselfde boek is ook in 1983 in die VSA gepubliseer met die titel: An eye for an eye. The place of Old Testament ethics today (Wright, 1983a). Hy wil dus die etiek van die Ou Testament pertinent bestudeer met die oog op die relevansie daarvan vir vandag. 
Hierdie verskillende benaderings het elk hulle eie waarde, soos uit bostaande bespreking blyk. Die oplossing wat Kaiser aan die hand doen, het besondere meriete, juis omdat dit nie op ' $n$ enkele faset konsentreer nie. In sy benadering kom die diakronie egter nie tot sy reg nie. Sy benadering kan sinvol aangevul word deur te let op die ontwikkelinge wat deur die loop van die Ou Testament plaasgevind het. Die veranderinge van die omstandighede van die volk het meermale ander eise gestel, met ander oplossings vir etiese vraagstukke.

\section{2 'n Raamwerk vir die bestudering van die Ou-Testamentiese etiek}

In die soeke na 'n raamwerk vir die bestudering van die etiek van die $\mathrm{Ou}$ Testament moet 'n mens natuurlik baie versigtig wees. Die werk van Hasel (1991) het oor jare, in verskillende uitgawes, aangetoon dat die soeke na 'n sogenaamde sentrum vir die Ou Testament 'n baie komplekse saak is. So 'n sentrale tema is al deur baie geleerdes op baie verskillende maniere geformuleer. Hasel (1991:139-171) toon verskillende moontlikhede aan en wys op die gevaar dat so 'n sentrale tema 'n sleutel kan word wat soms eerder versluierend as verhelderend werk. In die bespreking vir 'n moontlike raamwerk vir die bestudering van die etiek van die Ou Testament moet dié gevaar altyd in gedagte gehou word. Dit moet waarskynlik aanvaar word dat 'n enkele tema nie omvattend genoeg kan wees om reg te laat geskied aan die volle omvang van die openbaring van God in die Ou Testament nie. Gods openbaring geskied inderdaad oor ' $n$ lang tyd en op 'n verskeidenheid maniere deur 'n verskeidenheid van persone in baie verskillende omstandighede (vgl. Hebreërs 1:1). Tog bly dit steeds ' $n$ vraag of daar nie wel ' $n$ besondere tema is wat op 'n manier iets van 'n raamwerk kan bied vir die bestudering van die etiek van die Ou Testament nie.

Daar is reeds verwys na Kaiser se bespreking van die benadering van verskillende persone, ook wat die soeke na 'n sentrale raamwerk betref. Een poging wat hy egter nie vermeld het nie, verdien in dié verband besondere aandag, naamlik dié van Gordon Wenham (1978a). In sy benadering speel die verbond ' $n$ besondere rol. Die belangrike plek van die verbond vir die OuTestamentiese etiek word wel soms bevraagteken, veral deur geleerdes wat die verbond as 'n relatiewe laat ontwikkeling in die Ou Testament sien (vgl. Bosman, 1983:102-103). Dit is onmoontlik om hieraan volledige aandag te gee, maar Wenham se benadering is ' $n$ goeie voorbeeld van die hantering van die verbond as 'n raamwerk vir die Ou-Testamentiese etiek.

Wenham wys daarop dat die heilsgeskiedenis van die Ou Testament, na die rampspoedige begin van Genesis 1-8, op 'n reeks verbonde gegrond is (Wenham, 1978a:3). Die verbonde wat veral belangrik is, is die verbond met Abraham en Dawid en die verbond by Sinai. By al drie speel God se genade 'n besondere rol en staan dit voorop (Wenham, 1978a:4). Wenham wys wel op die belangrike verskil tussen die verbond met Abraham en Dawid aan die een kant en die 
verbond by Sinai aan die ander kant. In die verbonde met Abraham en Dawid word God se genade baie sterk beklemtoon, terwyl dit wat van die mens verwag word, op die agtergrond is. Hierdie twee verbonde toon ooreenkomste met die koninklike toeseggings in die Ou Nabye Ooste: God verbind Homself uit vrye wil aan spesifieke mense (Wenham, 1978a:4-5). Al het die verbond by Sinai 'n ander vorm en kom dit in sekere opsigte ooreen met die Buite-Bybelse vasalverdrae, staan God se genade ook voorop. Binne die raamwerk van die Sinaïtiese verbond ontvang die mens se verantwoordelikheid egter die meeste aandag. Die wette word geplaas in ' $n$ raamwerk van genadige Goddelike inisiatief. In Eksodus gaan die uittog uit Egipte die verbondsluiting vooraf. In Genesis 19:4 en 5 word die saak goed in perspektief gestel. Eers het God die volk uit Egipte verlos, waardeur hy hulle na Hom gebring het. Hierop volg dan die oproep dat hulle sy verbond moet gehoorsaam, waarop die belofte volg dat die volk God se eiendom uit al die volke sal wees, as hulle aan Hom gehoorsaam is (Wenham, 1978a:5). Die volgorde is dus hier belangrik, naamlik eers God se optrede, dan die eis, en dan die belofte van seën waarvoor gehoorsaamheid 'n voorwaarde is (Wenham, 1978a:6).

Wenham beklemtoon dit dat die wette van die Ou Testament binne die konteks van die verbond verstaan moet word. So bevat Eksodus 19 tot Levitikus 25 die bepalings van die verbond by Sinai, en Deuteronomium 4-26 die bepalings van die verbondshernuwing van Deuteronomium (Wenham, 1978a:9).

Op grond van hierdie bepalings maak Wenham ' $n$ aantal belangrike afleidings (Wenham, 1978a:9-13):

- Die wette van die Ou Testament is meer as bloot 'n abstrakte sisteem van moraliteit. Hierdie wette is die persoonlike eise van die soewereine, persoonlike God aan die volk wat aan hom onderhorig is. Deur gehoorsaamheid bevestig Israel hulle roeping om God se uitverkore volk te wees.

- Die verbondsraamwerk van die wet beklemtoon dat verlossing nie deur werke geskied nie. Die wette berus op genade.

- Die Ou-Testamentiese wetsversamelings bevat meer as net kasuïstiese wette. Kasuistiese wette is die vorm wat oorwegend in buite-Bybelse wetkodekse voorkom. Die Ou Testament bevat ook direkte opdragte (die sogenaamde apodiktiese wette) en bepalings oor godsdienstige sake. Die basiese bepaling bly dat die mens God met sy hele hart moet liefhê. Liefde is meer as net 'n gevoel, maar sluit in die getroue gehoorsaamheid aan alles wat God beveel het.

- Die verbond sluit ook seëninge en vervloekinge in. Levitikus 26 en Deuteronomium 28 is hiervan uitstaande voorbeelde. Gehoorsaamheid aan 
die verbond sal op seën uitloop. Die ander kant van die munt is egter dat ongehoorsaamheid straf tot gevolg sal hê. Dit is nie net die liefde vir God wat die mens aanspoor nie, maar ook die vrees vir Hom.

- Die verbond is ook onherroeplik. God kan nie sy beloftes verbreek nie.

Wenham gaan dan voort om die verdere verloop van die verbond in die $\mathrm{Ou}$ Testament te skets, met lyne na die Nuwe Testament. Hierdie benadering plaas die etiek van die Ou Testament binne 'n vaste konteks. Die etiese voorskrifte van die Ou Testament reflekteer nie 'n abstrakte, onpersoonlike sisteem nie, maar is 'n verwoording van die verbondsverhouding met God, waarin liefde tot die naaste ook 'n plek het. In hierdie verband beklee die Dekaloog 'n besondere plek - en dit is dus ook nie vreemd nie dat in die bespreking van die Christelike etiek die Dekaloog steeds 'n belangrike plek beklee (vgl. Geesink, 1931:231-449 en Wenham, 1978b). Sonder om die verbond as die sentrale tema vir die hele Ou Testament te aanvaar, kan egter wel aanvaar word dat die verbond 'n sinvolle vertrekpunt kan bied vir die bestudering van die etiek van die Ou Testament. Die mens se optrede teenoor ander mense kan nooit losgemaak word van sy verhouding met God nie.

\section{Hermeneutiek, Ou Testament en etiek}

In hierdie afdeling gaan, na enkele inleidende opmerkings, gelet word op 'n aantal voorbeelde van die gebruik van die Ou Testament vir die beantwoording van etiese probleme en daarna word die plek van die hermeneutiek ten opsigte van hierdie aangeleentheid meer volledig bespreek.

Dat die Bybel grondliggende waarde vir die Christelike etiek het, word seker deur die meeste Christene aanvaar. Tog is die gebruik van die Bybel in die etiek geen eenvoudige saak nie - en oor die wyse waarop die Ou Testament hierin 'n rol moet speel, bestaan daar nog minder eenstemmigheid. Douma (1983:43) wys byvoorbeeld op vier sake waarby mense met teenoorgestelde standpunte hulle op die Skrif beroep het, naamlik slawerny, onderdanigheid of opstand teenoor die owerheid, homoseksualisme en die reg op eiendom teenoor die staat se reg op onteiening. Binne die Suid-Afrikaanse konteks is die hele stryd oor apartheid seker die mees grondliggende voorbeeld in hierdie verband. In sekere kringe is apartheid eers as Skriftuurlik beoordeel en later is dit as verkeerd aangetoon ( $\mathrm{vgl}$. Deist, 1991:367).

Natuurlik is Douma reg as hy sê dat die misbruik van die Bybel nie die regte gebruik ophef nie (Douma, 1983:43-44), maar daarmee is die vraag nog steeds nie beantwoord oor hoe die Bybel, en spesifiek die Ou Testament reg gebruik moet word nie. Sowel die aanpassing van die Bybel by die mens van vandag as biblisisme bied geen sinvolle oplossings nie (vgl. Douma, 1983:44-45, 52-56). 
Hermeneutiese besinning is dus ' $n$ voorvereiste vir die gebruik van die Bybel in die bestudering van etiese vraagstukke.

\subsection{Enkele voorbeelde}

In die lig van die voorafgaande opmerkings moet positief geoordeel word oor die wyse waarop metodologiese besinning oor die gebruik van die Bybel in 'n proefskrif en 'n verhandeling wat hier bloot as voorbeelde gebruik word, aan die orde gestel word. In sy proefskrif handel byvoorbeeld Van der Walt (1989) by meer as een plek hieroor. In die bespreking van sy navorsingsmetode stel hy (Van der Walt, 1989:17): "Tweedens sal bepaalde aspekte, waar nodig, geidentifiseer word om volgens die eksegeties-openbaringshistoriese metode en met eksegeties-deduktiewe Skrifkontrolering, volgens 'n tematiese indeling behandel te word." In die hoofstuk waarin hy Skrifgegewens aan die orde stel, verwys hy weer na sy benadering (Van der Walt, 1989:114). In sy benadering wil hy 'n duidelike geheeloorsig bied, met die gevaar dat eksegetiese diepgang dan kan ontbreek. Hy wil egter sy perspektiwiese hantering van die groot hoeveelheid Skrifgegewens motiveer deur openbaringshistoriese Skrifuitleg en met deeglike eksegese begrond, waar nodig. Ten opsigte van laasgenoemde meld hy eksplisiet die goue reël van gereformeerde Skrifuitleg: Sacra Scriptura sui ipsius interpres. Later in die werk bied hy 'n belangrike uiteensetting in sy samevatting van belangrike bevindinge (Van der Walt, 1989:213). Hy wys op die gevaar om die Bybel as handboek vir etiese vraagstukke te probeer gebruik, waarsku teen 'n subjektiewe en biblisistiese Skriflantering en wys op die onderskeid tussen die tydgerigtheid en tydgebondenheid van die Bybel. $\mathrm{Hy}$ beklemtoon ook dat Skrifuitsprake nie sommer direk na vandag oorgedra kan word nie (vgl. ook Van der Walt, 1989:194-196). Die feit dat Van der Walt op hierdie wyse oor sy eksegetiese begronding nagedink het, is baie goed en sy waarskuwings gepas. Daar is egter nie spesifiek nagedink oor die wyse waarop die Ou Testament in die bespreking moet funksioneer nie. Verder word daar wel breë opmerkings gemaak, maar die bespreking is nie duidelik genoeg om alle vrae oor die Skrifgebruik te beantwoord nie. Wat is byvoorbeeld die verskil tussen "openbaringshistoriese Skrifuitleg" en "deeglike eksegese" (Van der Walt, 1989:114)? Sy eksegetiese vertrekpunte word nie duidelik en volledig genoeg aan die orde gestel nie.

In sy verhandeling wys Rheeder (1994:9) op die noodsaaklikheid dat die Bybel op die regte manier gehanteer moet word en dat die korrekte hermeneutiese reëls daarvoor nodig is. Hy gee dan, in aansluiting by Van Wyk (1986), dertien reëls waarvolgens hy die Skrif wil bestudeer (Rheeder, 1994:9-10). Hierdie reëls sluit grotendeels aan by dit wat tradisioneel in gereformeerde kringe geld. Dat Rheeder so 'n volledige uiteensetting gee, moet baie positief beoordeel word. Vir die doel van die plek van die Ou Testament in etiese besinning word 'n aantal 
belangrike sake aangeraak, wat nie in die inleiding verder beredeneer word nie. Punt 5 verwys na die onderskeid tussen tydgebonde en tydgerigte uitsprake en stel dat sommige gedeeltes in die Bybel duidelik tydgerig is. Punt 8 verwys na die ontwikkelingsgang en voortgang van die openbaringsgeskiedenis. Punt 10 stel dat die volkome en finale openbaring in Jesus Christus te vind is. Hierdie drie sake is vir die hantering van die Ou Testament van besondere belang en ' $n$ mens sou dus verwag dat hieraan spesifiek aandag gegee sal word by die bespreking van Ou-Testamentiese gedeeltes.

In sy latere hantering van die probleem waaroor hy handel, maak Rheeder ook die belangrike stelling dat die Bybel geen direkte uitsprake oor die onderwerp (surrogaatmoederskap) het nie, dat 'n finale antwoord dus ook nie moontlik is nie, maar dat daar tog fundamentele riglyne of grondbeginsels of gesigspunte in die Bybel gevind kan word (Rheeder, 1994:133-134). Rheeder gee dus 'n goeie uiteensetting van die beginsels waarvolgens hy die Bybel gaan gebruik. Ongelukkig kom die beginsels nie altyd in die praktyk van sy Skrifhantering na vore nie. Hy verwys byvoorbeeld na die belang van 'n nageslag as een van die argumente ten gunste van surrogaatmoederskap en verwys na Genesis $1: 28 ; 2: 15$; 28, 1 Samuel 10, Psalm 127 en 128 en Deuteronomium 25 (laasgenoemde in verband met die leviraatshuwelik). Al die gedeeltes kom uit die Ou Testament, maar die feit dat hulle in die Ou Testament voorkom, die moontlike tydgerigtheid van die gedeeltes en die lig van die volle openbaring in Christus kom glad nie in die bespreking aan die orde nie. Veral by die betekenis van die leviraatshuwelik sou 'n mens 'n breër bespreking verwag, aangesien daardie gebruik nie meer as geldig beskou word vir die moderne Christen nie. Ook die feit dat hy 'n nageslag aan die voortbestaan van 'n volk verbind, roep vrae op. Wat is die implikasies van die Nuwe-Testamentiese verandering in die posisie van die Godsvolk, wat nie meer net aan Israel kan verbind word nie?

In sy bespreking van surrogaatmoederskap in die lig van die skepping is dit vir Rheeder baie belangrik dat die mens 'n eenheidswese is (vgl. Rheeder, 1994:142144). As basiese Skrifgegewe hiervoor verwys hy na Genesis 2:7: "So het die mens 'n lewende wese geword." Hy oordeel dan dat surrogaatmoederskap hierdie eenheid van siel en liggaam deurbreek. In die bespreking word egter nie aandag gegee aan die feit dat die betrokke teks na die tyd voor die sondeval verwys nie en dus word daar ook nie gelet op die implikasies van die sondeval en die herstel in Christus op die betrokke teks nie. In hierdie geval neig sy hantering van die Bybel na die sogenaamde bewysteksmetode.

As derde voorbeeld word gelet op die hantering van gegewens uit die $\mathrm{Ou}$ Testament in die rapport oor die doodstraf wat in 1994 voor die Sinode van die GKSA gedien het (GKSA, 1994:609-611, 616-617). Uit die aard van so 'n studierapport word die bestudering van spesifieke gedeeltes uit die Bybel nie 
voorafgegaan deur 'n uiteensetting van hermeneutiese reëls en uitgangspunte nie. 'n Mens sou egter kon aanvaar dat reëls soos dié deur Rheeder gestel, ten grondslag van die bestudering sou lê. Dit gaan hier ook nie daaroor om die bevinding te beoordeel nie, maar slegs om te let op die gebruik van die Ou Testament in die argumentasie.

Genesis 9:6 ("Wie die bloed van 'n mens vergiet, deur 'n mens sal sy bloed vergiet word. God het die mens as sy beeld gemaak") word as die mees basiese uitspraak oor die doodstraf in die Ou Testament beskou (GKSA, 1994:609). Die argumentasie oor die mens as die beeld van God is oortuigend. Die volgende uitspraak verg egter nadere besinning (GKSA, 1994:609): "Deur hierdie bepaling wat vóór die bestaan van Israel as volk gegee is, maak die Skrif die doodstraf geldend vir alle mense van alle tye." In die wetgewing van Israel oor die doodstraf as die straf op moord word die wetlike omskrywing van die bepaling aangetref. Die klem wat hier gelê word op die feit dat hierdie bepaling voor die bestaan van die volk Israel gegee is en dus algemeengeldend is, verdien verdere aandag. Is dit nie moontlik dat ' $n$ bepaling wat voor die ontstaan van Israel gegee is, in Christus ter syde gestel kan word nie? Dit word nie in die studierapport beredeneer nie.

Die uitspraak van Genesis 9:6 moet natuurlik in sy eie konteks gelees word - iets wat in die studierapport nie aandag kry nie. Genesis 9:6 is deel van die verbond met Noag. In die verbond word die opdrag van Genesis 1:28 herhaal, naamlik dat die mens vrugbaar moet wees en vermeerder en die aarde moet vul. In Genesis 1:29 word die bevel opgevolg met 'n bepaling oor wat die mens mag eet, naamlik plante met saad en vrugte van bome. Ook in Genesis 9 word die opdrag van vers 1 opgevolg met ' $n$ bepaling oor wat die mens mag eet. Hier word die diere, benewens plante, aan die mens as voedsel gegee. Wat die diere betref, word egter bepaal dat die mens nie die bloed mag eet nie. In aansluiting hierby word dan na die vergieting van 'n mens se bloed verwys, met die straf daarvoor. In hierdie konteks is die bepaling oor die straf op die vergieting van 'n mens se bloed ten nouste verbind aan die verbod op die eet van dierebloed. Albei hierdie sake word later in die Israelitiese wetgewing verder gehanteer: die doodstraf in Eksodus 21:12, Levitikus 24:17 en Numeri 35:16-21 en die verbod op die eet van bloed in Levitikus 3:17 en Deuteronomium 12:16. Wat laasgenoemde betref, word die doodstraf in Levitikus 7:27 voorgeskryf vir iemand wat bloed eet. In Levitikus 17:10-14 word dit nog meer uitgebreid gestel. Wat Genesis 9:6 betref, stel Kidner (1968:101) die saak baie duidelik. Dié vers kan nie in 'n argument ten gunste van die doodstraf gebruik word sonder om ook die verbod op die eet van bloed te betrek nie. Sonder om hiermee 'n oordeel oor die studierapport uit te spreek, kan minstens gesê word dat hier 'n leemte in die beredenering is, wat weer met die sogenaamde bewysteksmetode saamhang. 
Wat die doodstraf in Ou-Testamentiese wette betref, word vier groepe misdade onderskei, naamlik religieuse misdade, misdade waardeur mense gedood is, morele misdade en seremoniële misdade (GKSA, 1994:609-610). In die verdere beredenering van die belang van die gegewens vir vandag, word alleen gehandel oor die gevalle waar mense gedood is. In die bespreking van die doel van die doodstraf word 'n onderskeid gemaak tussen die misdade waardeur mense gedood is en die ander misdade. Die res van die bepalings word nie meer as bindend vir vandag beskou nie, maar die saak word nie behoorlik beredeneer nie, terwyl die doodstraf vir moord wel behou word (vgl. GKSA, 1994:611). Die moontlike verskil tussen moord, strafbare manslag en wettige manslag word ook nie beredeneer nie. In die bespreking word verder aandag gegee aan persone wat moord gepleeg het, maar wat nie die doodstraf ontvang het nie, soos Kain, Moses en Dawid (GKSA, 1994:610-611). In nie een van die gevalle is daar volgens die rapport duidelikheid oor waaroor die doodstraf nie toegepas is nie. In die finale bevindinge figureer hierdie onsekerheid egter nie. Die lig wat die Nuwe Testament op hierdie sake werp, soos byvoorbeeld die belang van Christus se versoeningswerk op die seremoniële bepalings, kom glad nie aan die orde nie. Die vraag sou dus gevra kon word of die studierapport se verslag enige verskil toon met ' $n$ Jood se bestudering van die betrokke gedeeltes, terwyl ons juis as Christene die Ou Testament (behoort te) lees.

\subsection{Die hermeneutiese probleem}

Uit die gevalle wat hierbo bespreek is, is dit duidelik dat hermeneutiese besinning oor die gebruik van die Ou Testament in die beantwoording van etiese probleme steeds dringende aandag moet kry. Dit is onmoontlik om hier 'n oorsig te gee oor die ontwikkelinge op die terrein van die hermeneutiek, of selfs net van die wyse waarop dit vir die teologie van belang is nie. Vir 'n onlangse oorsig oor die terrein, vergelyk Thiselton (1992). Hier sal volstaan word met slegs enkele opmerkings om die problematiek van die verstaan van die Bybel te illustreer.

In die hermeneutiek kan breedweg twee benaderings onderskei word, naamlik 'n enger of ruimer siening van die taak van die hermeneutiek (vgl. Le Roux, 1993:34-35). Die enger siening is dit wat binne die tradisionele gereformeerde kringe aan die orde was, en tot 'n groot mate steeds is. Daarvolgens is dit die taak van die hermeneutiek om bloot reëls vir die verstaan van die Bybel te formuleer. Die breêr siening het egter te doen met meer as net die formulering van reëls, alhoewel dit steeds ter sake is. In die breër siening het hermeneutiek ook te doen met die hele verstaansproblematiek, met die filosofie wat 'n sekere metode onderlê. Nie net die reëls vir interpretasie nie, maar ook die kontekste van die eksegeet, die teks en die metode word bestudeer. In die tweede helfte van die twintigste eeu het hierdie breër siening al hoe belangriker geword en moet enige eksegeet daarvan kennis neem. Die ondersoek na die eie raamwerk, die eie 
paradigma, en die besef dat die eie raamwerk ' $n$ deurslaggewende rol in interpretasie speel, het in die hermeneutiese debat al hoe belangriker geword. In die interpretasie van enige gedeelte - en veral by die beoordeling van verskillende interpretasies - moet dit steeds in gedagte gehou word.

Soms kan mense binne dieselfde paradigma ook van mekaar verskil ten opsigte van die interpretasie van 'n spesifieke gedeelte, en soms is verskil aan interpretasie te wyte aan ' $n$ verskil in die basiese uitgangspunte. In albei gevalle kan die konteks van die verklaarder egter ook 'n rol speel.

Kaiser en Silva (1994:31-34) gee kortliks 'n tipering van vier verskillende metodes wat volgens hulle vandag algemeen in die interpretasie van die Bybel gebruik word:

\section{- Die bewysteksmetode}

Hierdie metode is eintlik verouderd, maar word nog gebruik, veral deur mense wat die Bybel wil gebruik om hulle standpunt te ondersteun. Met hierdie metode word 'n enkele teks, gewoonlik buite sy konteks, gebruik om 'n sekere standpunt mee te bewys of te ondersteun. Gewoonlik impliseer dit 'n naïewe lees van die Bybel. Die gebruik van tekste buite hulle konteks is 'n gevaar waarteen 'n Christen-wetenskaplike steeds moet waak, asof die aanhaal van 'n aantal tekste wetenskapsbeoefening Christelik maak.

\section{- Die histories-kritiese metode}

Hierdie metode is steeds die oorheersende paradigma in bibliologiese studies aan die einde van die twintigste eeu. Meermale word die openbaringskarakter van die Bybel deur die gebruikers van die metode ontken. Met hierdie metode word dikwels op die bronne agter die teks gekonsentreer en word gepoog om die sosiale raamwerk waarbinne die teks, sy bronne en tradisies ontstaan het te bepaal. Die historiese betekenis is die fokuspunt.

\section{- Resepsie-estetiese metodes}

'n Nuwer benadering wat sterk veld gewen het, hou verband met ontwikkelinge in die literatuurwetenskap, naamlik die gebruik van resepsie-estetiese (readerresponse) metodes. Met hierdie benaderingswyse word besondere aandag aan die rol van die leser gegee, in aansluiting by hermeneutiese modelle ontwerp deur persone soos Gadamer en Ricoeur.

\section{- Die sintakties-teologiese metode}

Kaiser en Silva noem die metode wat hulle wil gebruik die sintakties-teologiese metode, wat in wese nie verskil van die sogenaamde grammaties-historiese eksegese wat in gereformeerde kringe gebruik is en dikwels nog gebruik word 
nie. Met hierdie metode word op die letterlike en historiese betekenis van die teks van die Bybel in sy huidige vorm gekonsentreer.

Uit die aard van die saak sal persone wat hierdie verskillende modelle gebruik, verskillende metodes volg by die interpretasie van 'n teks en normaalweg ook verskillende resultate bereik. Hierdie aspek van verskillende metodes en interpretasies toon die samehang tussen uitgangspunt, metode en resultate aan.

Om die invloed van verskillende benaderings aan te toon - selfs by persone wat basies dieselfde uitgangspunte deel - kan verwys word na die lesing van Genesis 9:6 by Kidner en by die studierapport voor die Sinode van die GKSA in 1994. Die twee lesings is reeds vroeër in die artikel bespreek. Kidner, wie se kommentaar in die reeks Tyndale Commentaries gepubliseer is, werk binne die tradisionele grammaties-historiese model en het basies 'n konserwatiewe benadering tot die Bybel en tot Genesis in die besonder. Dit lyk nie volgens sy kommentaar of daar iets in sy standpunt is wat vir mense binne die reformatoriese tradisie onaanvaarbaar sal wees nie. 'n Mens kan dus aanvaar dat sy teoretiese en hermeneutiese vertrekpunte en dié van die opstellers van die studierapport grotendeels ooreenstem. Tog is daar 'n verskil in hulle standpunte oor Genesis 9:6. Die verskil is daarin geleë dat hy binne die grammaties-historiese metode klem lê op die verband van die betrokke Skrifgedeelte, terwyl die opstellers van die studierapport nie eksplisiet aan daardie verband aandag gee nie. Die studierapport is dus eerder verteenwoordigend van die bewysteksmetode.

Om die verband tussen hermeneutiese model en die interpretasie van die $\mathrm{Ou}$ Testament vir die etiek te verduidelik, kan gelet word op die plek wat aan die Dekaloog toegeken word. Reeds Calvyn het in sy Institusie (Boek 2, hoofstuk 8; Calvyn, 1966) 'n besondere plek toegeken aan die Dekaloog, wat hy die morele wet genoem het. Hy het daarop gewys dat nie by die blote letterlike betekenis van die wet vasgesteek moet word nie, maar dat na die beginsel agter elke gebod deurgedring moet word, om dan daarvan verder te beweeg in die toepassing van die wet (Institusie 2,8,8; Calvyn, 1966). Sedert Calvyn het die Dekaloog dus 'n besondere plek beklee in die gereformeerde etiek. Hier kan ook byvoorbeeld gewys word op die belangrike plek van die Dekaloog in die derde deel van die Heidelbergse Kategismus. Dit is dus ook nie vreemd dat in die Gereformeerde ethiek van Geesink meer as 200 bladsye aan 'n bespreking van die Dekaloog afgestaan word nie (Geesink, 1931:231-449). Wat ook van Geesink gewaardeer moet word, is sy poging om werklik eksegeties verantwoord met die verskillende gebooie om te gaan, terwyl hy ook let op die geskiedenis van die gebruik van die verskillende gebooie in die etiek deur die geskiedenis heen.

Wenham (1978b) is 'n goeie voorbeeld van die bestudering van die Tien Gebooie binne die normale reformatoriese raamwerk. Hy stel dat die Dekaloog ten regte as die kern van die wet in die Ou Testament beskou word (Wenham, 1978b:27). 
Die Dekaloog kan ook beskou word as 'n uiteensetting van die basiese religieuse en etiese beginsels (Wenham, 1978b:28). Die Dekaloog moet volgens hom beskou word as die hart van die verbondswetgewing, 'n besondere openbaring van God in die volle sin van die woord (Wenham, 1978b:29). In sy bespreking van die verskillende gebooie gee hy bloot 'n eksegetiese uiteensetting van die Dekaloog in sy verbondskonteks, sonder om volledig lyne na die Christen van vandag deur te trek. Hy maak wel enkele opmerkings wat lig werp op sy siening van die betekenis van sommige van die gebooie vir vandag, soos by die vierde gebod dat die Sondag in die nuwe bedeling die opstanding herdenk (Wenham, 1978b:32).

Douma (1983:64-82) se bespreking van die betekenis van die Dekaloog vir die etiek gaan van dieselfde soort beskouing van die Dekaloog as Wenham uit. Dié benadering verbind die Dekaloog aan God en sy openbaring en gee dus 'n besondere gesagvolle plek daaraan. Hy doen dit egter op 'n hermeneuties verantwoorde wyse, waarin daarmee rekening gehou word dat die Dekaloog in die Ou Testament staan en dat dit in die lig van die verlossingswerk van Christus gelees moet word. Hy wys daarop dat vir Calvyn die wil van God vir die gelowige se lewe sy uitdrukking gevind het in die Dekaloog en dat die verklaring van die Dekaloog deur die eeue die ruggraat vir die etiese onderrig in gereformeerde kerke gevorm het (Douma, 1983:66). 'n Belangrike opmerking van Douma is dat die kerk wel nie by Sinai kan bly staan nie. In die Christelike etiek moet steeds uitgegaan word van wat Christus gedoen het en alleen via Hom kom die Christen voor die Tien Gebooie te staan (Douma, 1983:70). Christus het op die diepte van die gebooie gewys en 'n Christen mag dus nie bly stilstaan by 'n oppervlakkig-letterlike lees van die wet nie (Douma, 1983:70). Verder is Christus as die vervulling van die wet ook belangrik, sodat daar altyd van die persoonlike verhouding met God uitgegaan moet word (Douma, 1983:71). Al die mens se handelinge moet dus 'n Christosentriese karakter dra (Douma, 1983:71). Hy wys byvoorbeeld op die betekenis hiervan vir die Sabbatsgebod, wat binne die kerk te veel 'n sabbatistiese stempel gedra het (Douma, 1983:72). 'n Sondagsviering wat met die werk van Christus verband hou, lyk anders as iets wat bloot in reèl op reël vasgevang is. Hy oordeel dus dat die Tien Gebooie vandag met vertroue aan die kerk voorgehou kan word as kerngebooie, maar dan moet ' $n$ mens altyd die lig van Christus daarop laat skyn (Douma, 1983:73).

'n Ander benadering tot die Dekaloog word aangetref in die bydrae van Mayes (1991) in 'n versamelbundel met die titel Ethics and the Christian. Die titel van sy artikel is reeds veelseggend: "The Decalogue of Moses: an enduring ethical programme?" Hy oordeel ook dat die Dekaloog in die kerk steeds 'n fundamentele betekenis het, maar dat dit tog iets van sy betekenis in die kerk verloor het (Mayes, 1991:26). Hy wil probeer om die sentrale betekenis van die Dekaloog te vind en om te bepaal wat die betekenis daarvan vir vandag is, maar 
doen dit as iemand binne die historiese (histories-kritiese) tradisie. Vir hom is die Dekaloog nie 'n vaste teks nie, maar 'n meer vloeibare tradisie (Mayes, 1991:27). Laasgenoemde hou vir hom onder andere verband met die twee weergawes van die Dekaloog - in Eksodus en Deuteronomium (Mayes, 1991:38). Vir Geesink was dit nie 'n probleem nie. Hy gaan uit van die inspirasie van albei gedeeltes en het dan nie 'n probleem om te aanvaar dat die inspirasie by die twee geleenthede verskil het nie (Geesink, 1931:232). Vir Mayes is die Dekaloog nie die produk van inspirasie nie, maar van 'n lang groeiproses in die ontwikkeling van Israel. Vir hom is die Dekaloog nie wet nie, maar onderrig (Mayes, 1991:30). Dit hou verband met die apodiktiese styl van die Dekaloog, wat verskil van die normale kasuisties-geformuleerde wette. As onderrig stel dit die grense waarbinne iemand in die gemeenskap kan beweeg. Die Dekaloog kan dus nie maar sommer as die Woord van God bestempel word nie (Mayes, 1991:32); dit is eerder iets van 'n basisdokument geformuleer vir 'n geloofsgemeenskap (Mayes, 1991:322-33). Hy dateer die Dekaloog in die laat voor-eksiliese periode en sien dit as ' $n$ neerslag van Israel se groeiende tradisie en onderrig, en nie as 'n goddelike geskenk wat los van geskiedenis en ervaring gegee is nie (Mayes, 1991:33-34). Volgens Mayes is die Dekaloog nie 'n openbaring van God by Sinai nie, maar ' $n$ insig geformuleer in deuteronomistiese kringe (Mayes, 1991:34). Hierdie insig was steeds onderworpe aan herinterpretasie, soos wat dit veral radikaal in die Bergrede geherinterpreteer is (Mayes, 1991:39). Die Dekaloog is dus "oop", ook vandag steeds oop vir 'n nuwe interpretasie. Tog is daar vir iets wat konstant is, naamlik die insig dat die diens van God respek impliseer vir die integriteit van ander en omgekeerd.

Binne hierdie soort benadering is daar nie veel plek vir wat gewoonlik preskriptiewe etiek genoem word nie - anders as in die meer tradisonele gereformeerde benadering van Wenham en Douma. Binne die raamwerk van hierdie benadering sal elke geslag moet soek na 'n nuwe interpretasie in die lig van nuwe omstandighede en word etiek vloeibaar. Natuurlik is 'n nuwe interpretasie in nuwe omstandighede ' $n$ vanselfsprekendheid. Die konteks van die interpreteerder speel 'n belangrike rol in die vrae wat gevra word, maar tog moet daar steeds antwoorde gegee word wat verband hou met die Bybelse boodskap binne sy oorspronklike konteks.

Waar Douma binne die tradisonele model van grammaties-historiese eksegese werk en Mayes binne die histories-lritiese model, sou 'n mens waarskynlik kan sê dat die Heidelbergse Kategismus meer die bewysteksbenadering volg. Dit is natuurlik heeltemal verstaanbaar, aangesien dit basies die eksegetiese model van die tyd van die Kategismus was. Ter illustrasie kan na die Kategismus se verklaring van die vierde en tiende gebod gekyk word. Geesink (1931:359-360) wys daarop dat die Kategismus in die verklaring van die sewende gebod die interpretasie van Calvyn in sy Institusie navolg. Calvyn wil naamlik nie 
besondere klem plaas op die getal sewe nie, maar wil 'n spesifieke dag vir kerklike byeenkomste handhaaf - ter wille van orde. Volgens Geesink het Calvyn meer klem gelê op een dag rus in sewe dae in sy Genesiskommentaar. In die Kategismus se verklaring van die Sabbatsgebod kom daar veral drie sake na vore, naamlik die onderhouding van die Woordbediening en die skole (waarmee waarskynlik skole vir opleiding van predikante bedoel word), die gereelde saamkoms van die gemeente op wat die rusdag genoem word, en die begin van die ewige sabbat in hierdie lewe deur die daaglikse rus van bose werke. Geesink wil in sy eie verklaring van die vierde gebod veral drie sake beklemtoon, naamlik dat die gelowiges navolgers van God moet wees (met een dag rus in sewe), die onderhouding van die inwendige sabbat (soos aan die einde van die Kategismus se verklaring) en die onderhouding van die uitwendige sabbat (Geesink, 1931:365-367). Dit is duidelik dat die Kategismus se verklaring direk wil handel oor wat die vierde gebod vir die gelowiges vandag sê, terwyl die dinge wat die gebod in sy oorspronklike konteks ingehou het (vgl. Wenham, 1978b:32), totaal op die agtergrond is.

Die tiende gebod handel in sy oorspronklike konteks oor die begeerte om iemand anders se besittings te verkry (vgl. Fensham, 1970:141-142 en Wenham, 1978b:38). Innerlike begeertes is natuurlik nie deur die wet strafbaar nie, maar in die tiende gebod kan die innerlike aard van die Ou-Testamentiese etiek duidelik raakgesien word. Die verklaring van die Kategismus verskil egter hiervan, deurdat dit die tiende gebod verbind aan enige begeerte om enige van die gebooie van God te oortree. Calvyn (Institusie 2,8,49-50) se verklaring neig ook in dié rigting, alhoewel hy die verkeerde begeertes in die voorbeelde wat hy bespreek, net aan die tweede tafel van die Tien Gebooie verbind. Geesink onderskryf egter die Kategismus se interpretasie as hy stel dat die tiende gebod oor slegte begeertes in die algemeen handel (Geesink, 1931:446-448). Hier wyk Geesink af van sy normale letterlike interpretasie om tot 'n meer geestelike interpretasie te kom. In die geval van die vierde en tiende gebod is die Kategismus se interpretasie duidelik deur die Institusie van Calvyn beinvloed en dra die eksegetiese model wat die interpretasie ten grondslag lê, die tekens van sy tyd.

\section{Slot}

Omdat die Ou Testament deel van die kanon van die kerk is, is dit belangrik dat die Ou Testament ook sy regmatige plek moet inneem in debatte oor moderne etiese kwessies. Die besondere plek wat die Dekaloog in die teologiese etiek binne die reformatoriese tradisie ontvang het, moet ook gewaardeer word. Tog is dit uiters belangrik dat die Ou Testament op ' $n$ verantwoordelike wyse ontgin moet word. Etici se vak is natuurlik nie in die eerste plek eksegese nie, maar as hulle - ten regte - hulle etiese uitsprake eksegeties wil begrond, moet die eksegese verantwoordelik gedoen word, met gebruikmaking van 'n verantwoorde 
eksegetiese metodiek. Dit is nie voldoende om 'n goeie uiteensetting van vertrekpunte of selfs hermeneutiese reëls te gee nie. Die eksegese moet daarvolgens gedoen word. Dit beteken dat daar meer indringende eksegetiese werk gedoen sal moet word en dat daar steeds kennis geneem sal moet word van ontwikkelinge op die terrein van die hermeneutiek en die eksegese. Indien dit nie gedoen word nie, kan pragtige etiese konstruksies op sand gebou word.

\section{Bibliografie}

BARTON, J. 1985. Approaches to ethics in the Old Testament. (In Rogerson, J. ed. Beginning Old Testament study. London: SPCK. p. 113-130.)

BOSMAN, H.L. 1983. Taking stock of Old Testament ethics. Old Testament Essays, 1:97104.

CALVYN, J. 1966. Institutes of the Christian religion. Translated by Henry Beveridge. Grand Rapids, Michigan : Eerdmans.

DEIST, F.E. 1991. Objektiewe Skrifuitleg? Kanttekeninge by Skrifuitleg in die Ned Geref Kerk 1930-1990. Hervormde Teologiese Studies, 47(2):367-385.

DOUMA, J. 1983. Verantwoord handelen Kok: Kampen.

FENSHAM, F.C. 1970. Exodus. (De prediking van het Oude Testament) Nijkerk : Callenbach.

GEESINK, W. 1931. Gereformeerde Ethiek I. Kok: Kampen.

GEREFORMEERDE KERKE IN SUID-AFRIKA 1994. Handelinge van die vyf-en-veertigste Nasionale Sinode. Potchefstroom.

GKSA

kyk

GEREFORMEERDE KERKE IN SUID-AFRIKA.

HASEL, G.F. 1991. Old Testament theology: Basic issues in the current debate 4th. ed Grand Rapids, Michigan : Eerdmans.

KAISER, W.C. 1983. Toward Old Testament ethics. Grand Rapids, Michigan : Academic Books.

KAISER, W.C. \& SILVA, M. 1994. An introduction to Biblical hermeneutics. The search for meaning. Grand Rapids : Zondervan.

KIDNER, D. 1968. Genesis. (Tyndale Old Testament Commentaries) London: Tyndale Press.

LE ROUX, J.H. 1993. A story of two ways. Thirty years of Old Testament scholarship in South Africa. (Old Testament Essays Supplement 2.) Pretoria : Verba Vitae

MAYES, A.H.D. 1991. The Decalogue of Moses: An enduring ethical programme? (In Freyne, S. ed. Ethics and the Christian. Dublin : Columba Press. p. 25-40.)

RHEEDER, A.L. 1994. Surrogaatmoederskap teologies-eties beoordeel Potchefstroom PU vir CHO. (Th.M.-verhandeling.)

THISELTON, A.C. 1992. New horizons in hermeneutics. Grand Rapids : Zondervan. 
VAN DER WALT, S.J. 1989. Die roeping van die kerk ten opsigte van etiese vraagstukke in die samelewing met toespitsing op uitsprake van sinodes van die Gereformeerde Kerke in Suid-Afrika. Potchefstroom : PU vir CHO. (Th.D.-proefskrif.)

VAN WYK. J.H. 1986. Gesindheid en gestalte. Pretoria : NG Kerkboekhandel.

WENHAM, G. 1978a. Grace and law in the Old Testament. (In Kaye, B. \& Wenham, G eds. Morality and the Bible. Downers Grove, Illinois : InterVarsity Press. p. 3-23.)

WENHAM, G. 1978b. Law and the legal system in the Old Testament. (In Kaye, B. \& Wenham, G. eds. Morality and the Bible. Downers Grove, Illinois : InterVarsity Press. p. 24-52.)

WRIGHT, C.J.J. 1983a. An eye for an eye. The place of Old Testament ethics today. Downers Grove, Illinois : InterVarsity Press.

WRIGHT, C.J.J. 1983b. Living as the people of God. The relevance of Old Testament ethics. Leicester : InterVarsity Press. 
